\title{
Is the High-Speed Rail Opening Environmentally Friendly? Taking the Difference-in-Differences Test in Jiangsu, China
}

\author{
Shijin Wang (iD, Huiying Zhou $(\mathbb{D}$, and Guihong Hua \\ School of Business, Jiangsu Normal University, Xuzhou 221116, Jiangsu Province, China \\ Correspondence should be addressed to Shijin Wang; wangshijin2008@126.com
}

Received 2 March 2020; Accepted 21 April 2020; Published 20 May 2020

Guest Editor: Felix Chan

Copyright (c) 2020 Shijin Wang et al. This is an open access article distributed under the Creative Commons Attribution License, which permits unrestricted use, distribution, and reproduction in any medium, provided the original work is properly cited.

\begin{abstract}
In view of rapid development of high-speed rail, the relationship between high-speed rail and air pollution needs to be tested and determined. Most research studies focused on the impact of high-speed rail on environmental pollution and just viewed highspeed rail as a control variable, which lacked a direct study on this relationship. Also, these rarely involved regional research, which is short of pertinence and insufficient understanding of regional issues. Therefore, based on the difference-in-differences (DID) model which is a natural experiment evaluation method, this study examined the impact of high-speed rail opening on air pollution by using the panel data of Jiangsu province, China, from the year of 2000 to 2017. The empirical results showed that the opening of Jiangsu high-speed rail, which increases cities' good day significantly by $21.5 \%$, has inhibitory effect on air pollution. Among control variables, there is no inverted " $U$ " relationship between the economic development level and air pollution. Personal income and urbanization significantly improve air pollution, whereas foreign direct investment exacerbates it. And the results are still valid after robustness tests, including trend test and counterfactual test. Moreover, this study explores the relationship between the degree of reducing pollution caused by high-speed rail and the location of cities, which found that the opening of high-speed rail can greatly improve air pollution of areas in central city circle. Finally, it is found that when high-speed rail and other possible pollution items coexist, the improved effect of high-speed rail on air pollution is still obvious. Therefore, in order to exert the mitigating effect of high-speed rail on air pollution, it is necessary to rationally plan high-speed railway lines and develop the high-speed railways in cities closer to Shanghai.
\end{abstract}

\section{Introduction}

Since the 20th century, with the advancement of science and technology, high-speed railways have been an inevitable trend of economic and social development, and all countries in the world are accelerating the construction of high-speed railways. Although China's high-speed railway construction started late, it has developed rapidly. By the end of 2018, China's high-speed rail operating mileage reached more than 29,000 kilometers, and it has become the railway system with the most complete technology, the strongest integration capability, the longest operating mileage, the highest operating speed, and the largest scale of construction in the world. As one of the most developed provinces in China, Jiangsu keeps high economic growth rate and fast railway construction. In July 2010, the Shanghai-Nanjing intercity railway was completed and opened to traffic, and it has become an important symbol because it represents the first modernization of railways in eastern China. However, there exists a close relationship between high-speed railways and environmental pollution, which mainly comprises air pollution, water pollution, noise pollution, vibration and lowfrequency sound, and various kinds of pollution that occur during construction of the railway. The high-speed railway noise sources can be roughly divided into the following categories: the wheel-rail noise generated by the high-speed trains, the collector system noise generated by the train pantograph and the contact network wire friction, the aerodynamic noise of the high-speed running train, the secondary radiation noise generated by the vibration of the building foundation, and the mechanical noise from the power sources and on-board equipment [1]. The sewage 
along the high-speed railway mainly comes from the production and maintenance sites of the automatic trains, highspeed trains, motor trains, engineering sections, and power supply sections, which comprises oily sewage, domestic sewage, car wash waste water, and highly concentrated fecal sewage. The solid waste along the route mainly comes from the garbage generated from the trains, stations, railway offices, and other living places as well as a small amount of industrial solid waste generated from the maintenance work of the section. There are also many environmental impact factors that arise during the construction period, which include disturbing the surface, damaging the surface vegetation, destroying the original topography, and basic farmland occupation as well as factors that affect the nature reserve, natural landscape, human landscape, and cultural and historical sites. The impact of bridge and culvert construction on the water environment includes the impact on the water quality, the water resources protection zone, and the aquaculture industry. The construction machinery has impacts on the acoustic environment and causes environmental vibrations, and these affect residential areas, hospitals, schools, and offices, and the construction vehicles and sand and gravel yards have impacts on the quality of the air. Commonly, air pollution is closely related to human survival, which has affected the evolution of respiratory diseases in exposed people worldwide and even endangered life [2, 3]. Nowadays, China actively promotes the construction of an ecological civilization and strong ecological protection, which puts higher standards on the construction of highspeed rail. Therefore, the relationship between the highspeed railways and air pollution is analyzed to see whether high-speed rail construction will aggravate the air pollution in Jiangsu province, and corresponding suggestions are proposed for improving the atmospheric environment and the construction of high-speed rail.

When researching the impact of high-speed rail, the scholars mostly focus on its economic effects. The opening of high-speed rail has changed the spatial and temporal distribution pattern between cities, which had a growth effect and structural effect on the economic development of these cities. It reduces the industrial transfer costs, the commuting time, and income gap while promoting industrial agglomeration, urban development, economic equalization, and integrated development $[4,5]$. The urban agglomeration economic effect is more pronounced in the west; the highspeed railway helps the economic resources to gather in the western region, which is beneficial to the equalization of the economy [6]. However, not all high-speed railway lines have such significant regional economic effects. For example, it was found that the Shanghai-Hangzhou high-speed railway has a significant effect on industrial transformation, the gathering of scientific and technological talents in the cities along the rail line, and the division of industrial labor, but it has not been a big driving force towards closing the regional economic gap [7]. Scholars have studied the impact of the high-speed rail opening on the population distribution and urbanization development, and they found that the highspeed rail opening had an overall effect, heterogeneous effect, and industrial effect on the urban population distribution pattern. The high-speed rail opening significantly reduced the urban population density [8]. In the short term, the high-speed rail construction reduced the population size of the high-speed rail cities in the central and western regions, which is not conducive to the improvement of the urbanization level in such cities [9]. In addition, studies showed the impact of high-speed rail traffic on social and economic operational efficiency and venture capital from the perspective of economic costs $[10,11]$. So, does the economic benefit of high-speed rail also imply that there are similar environmental benefits?

In the existing literature, there are few studies on highspeed rail and atmospheric pollution. The environmental effects of the opening of high-speed railways mainly focus on the following two aspects. On the one hand, the development of high-speed rail promotes environmental improvement. Studies have shown that adjusting peak pollutant emission parameters can accelerate the development of energy intensity and environmental quality and eventually stabilize at a certain level [12]. And the characteristics of high-speed rail are that it is clean, stable, and operates at high-speed, all of which reflect its environmental advantages. Taking the Wuhan-Guangzhou high-speed railway as an example, it is concluded that every kilometer of high-speed rail represents more than 2,150.55 tons of carbon dioxide per year [13]. At the same time, the green economy effects of high-speed rail include the promotion of the development of the tertiary industry, acceleration of the development of the industry in terms of its specialization and depth, and the promotion of the optimization and upgrading of the industry, all of which are positive impacts indirectly alleviating the environmental pressure. Compared with the secondary industry, the tertiary industry has reduction effect and technology intensiveness. High-speed railways can promote the aggregation of such industries and improve the quality of the service industry, which thereby reduces air pollution. It is believed that China's high-speed railways have a significant carbon reduction effect compared with other modes of transportation and that operation of the high-speed railways produces a benign mutual feedback between the economy and environment [14]. At the same time, the benign interaction between high-speed rail and the environment has regional heterogeneity. It has been found that the opening of high-speed rail services has reduced the carbon emissions in the eastern cities and increased them in the central and western regions [15]. Also, the upper reaches of the Yangtze River Economic Belt are more effective in mitigating environmental pollution than the middle and lower reaches [16]. On the other hand, the pollution created in the construction process is serious and aggravates the air pollution. The negative impacts come from the operation of the highspeed rail system and from its construction. The high-speed rail construction consumables damage the environment, the operation of the high-speed rail causes both noise and vibration, and these have the greatest impact on the environment. In addition, the growing speed construction of the high-speed rolling stock leads to a large amount of energy consumption, which indirectly aggravates air pollution. It has been found that the environmental pollution caused by 
the high-speed rail infrastructure in the early stages is more serious than that caused by the traditional railway [17]. Most of the above scholars used the DID model for their research, and some used life cycle assessment (LCA) methods to conduct their research. The Chinese Core Life Cycle Database has been used to explore the impact of high-speed rail planning and construction changes [18].

In summary, the following points still need to be highlighted. (1) Few literatures studied on high-speed rail and air pollution; it is important to study the relationship between the two and to determine how to control the air pollution arising from high-speed rail activities. (2) The existing research has been carried out with a whole nation, and there are basically blanks at the regional level. Each region has its own characteristics, and focusing on the regional areas will contribute to better development of the regions. (3) There are fewer tests for robustness in the application of the DID model. As a quasinatural experiment, multiple robustness tests can better explain the experimental results. Therefore, this study takes 13 cities in Jiangsu province as the research object, uses the DID model to carry out various forms of robustness tests, and comprehensively explores the impact of high-speed rail opening on the air pollution in Jiangsu province.

\section{Theoretical Assumptions}

As part of the transportation infrastructure, the construction and operation of high-speed railways have an inhibitory effect on air pollution for three reasons. First, the high-speed rail's low-carbon energy-saving characteristics make it an important way to reduce air pollution. The transportation industry has always been closely related to the atmospheric environment. On the one hand, transportation development is based on resource and environmental constraints. Its development means the reduction of resources and an increase in atmospheric pollution. On the other hand, the quality of the resources and atmospheric environment determines whether transportation can continue to develop steadily. Therefore, the development of transportation should minimize the energy consumption and reduce air pollution in order to achieve a balance between traffic development and atmospheric stability [19]. Studies have shown that high-speed rail has a traffic substitution effect [20]. Compared with the high pollution and high energy consumption of ordinary railway and road transportation, high-speed rail has clean energy and energy-saving characteristics and also has the advantages of punctuality, safety, and comfort. It uses electric energy to drive the rolling stock, which largely eliminates dust and soot pollution, and electric locomotives consume less power. For example, the energy consumption of the Revival multiple unit (MU) train is only $3.8 \mathrm{kWh}$ per capita. Therefore, the operation of high-speed trains can reduce air pollution and improve the air quality. Second, the economic effects brought about by the opening of the high-speed rail have further improved air pollution. The high-speed rail has produced changes in transportation and improved traffic conditions in various regions. The degree of openness between regions has been expanded, which has accelerated the speed of circulation of factors among the regions and thereby achieved economies of scale, technological innovation, and upgrade of the industrial structure. These green economic effects promote regional economic development, provide financial guarantees for air pollution control, bring other good environmental effects, and promote a virtuous cycle of environmental quality improvement, which thereby indirectly reinforces the role of high-speed rail in promoting the air quality. Finally, the opening of the high-speed rail has effectively narrowed the spatial distance between cities and reduced the cost of the joint control of air pollution between regions and the cost to drive the reduction of air pollution. High-speed railways connect areas with different levels of economic development, which enhances the connection between regions and thus makes it easier to construct a joint prevention and control mechanism for air pollution. In areas with pollution conditions and development conditions, it is easier to coordinate the respective pollution control quantities through high-speed railways in order to improve the regional air quality. Therefore, this study presents the first hypothesis to be verified.

$\mathrm{H} 1$ is that the opening of high-speed railways will reduce air pollution.

For the opening of high-speed rail, geographical location and economic development level will lead to differences in the degree of improvement in air pollution caused by the opening of the high-speed rail. Studies have shown that the strategic position of central cities in the level of economic development will affect the high-speed rail network planning itself, and the economic development level of the remaining cities along the way is not the direct reason for determining whether the high-speed rail should be opened [21]. This shows that the construction of high-speed rail has a certain exogenous influence and is greatly affected by the central city. Jiangsu province is located on the eastern coast of mainland China, which constitutes the Yangtze River Delta urban agglomeration with Shanghai, Zhejiang, and Anhui. The overall location advantage is obvious, but the geographical location of each city is obviously different. The opening of the high-speed railway broke the geographical division between the cities by narrowing the distance between the central city and the high-speed rail city and expanding the boundary of influence of the central city group. The central city attaches great importance to the air quality, a strong pollution control capability, and its advanced treatment technology. Therefore, the opening of high-speed rail can enable the central city to play a good demonstration role, provide experience for the air pollution control of its surrounding cities, and promote the technological innovation of pollution control in the surrounding cities. It is also possible to increase the proportion of the tertiary industry and promote industrial upgrading through industrial transfer, thereby reducing the air pollution brought by the secondary industry. In contrast, high-speed rail cities that are not in the central city circle are remote, their pollution control lags behind, and the governance effects obtained by the high-speed rail cities near the central city cannot be achieved. In short, the opening of the high- 
speed railway strengthened the green "spillover effect" of the central city and improved the quality of the atmosphere. Based on the above analysis, this study proposes a second hypothesis to be verified.

$\mathrm{H} 2$ is that compared with other cities along the highspeed railway, cities along the high-speed railway in the central circle have more significant air pollution mitigation effects.

\section{Research Design}

3.1. Modeling. Because it is part of a national-level strategic plan, high-speed railway construction cannot usually be controlled by the provinces. Therefore, it can be regarded as a "natural experiment," and the DID model is used to evaluate its policy effects. The model was first introduced in 1985 , and it was widely used in the quantitative evaluation of public policy or project implementation effects in econometrics [22]. For example, some scholars use this method to study the impact of joint implementation (JI) mechanisms on pollution control in two bilateral countries [23]. Therefore, this study draws on this approach and uses the DID method to evaluate the impact of the high-speed railways on air pollution in Jiangsu province. The DID method evaluates the policy effect by emulating the contrast method in the natural science experiment. Therefore, this study selects six cities that opened high-speed rail between 2000 and 2017 as the treatment group and seven cities without high-speed rail as the control group. Due to the differences in the time of opening high-speed railways, the DID model is realized by the two-way fixed effect model, which controls the fixed effect of time and the individual fixed effect of the city. The model is set as follows:

$$
\text { Goodday }_{i, t}=\alpha_{i, t}+\beta G_{i, t}+\lambda X_{i, t}+\gamma_{t}+\mu_{i}+\varepsilon_{i, t},
$$

where $i$ represents the city and $t$ represents the year. Goodday $_{i, t}$ is the explanatory variable. $G_{i, t}$ is the dummy variable for the opening of the high-speed rail city, $G_{i, t}=1$ indicates that city $i$ is a high-speed rail opening city in year $t$, and $G_{i, t}=0$ indicates that city $i$ is not a high-speed rail opening city in year $t . X_{i, t}$ is a control variable, and it includes the per capita GDP, tertiary industry added value, disposable income of urban residents, foreign direct investment, and the urbanization rate. $\gamma_{t}$ represents the time fixed effect, and $\mu_{i}$ represents the urban individual fixed effect. According to the hypothesis, this study focuses on the $\beta$ value. If $\beta>0$, it indicates that the high-speed rail opening increases the number of days with good air quality and mitigates air pollution.

3.2. Data Declaration. Explanatory variable is good air quality days (Goodday). Scholars have investigated air pollution based on two methods. One of these is a single indicator, and this is usually industrial waste gas, sulfur dioxide, industrial dust, or $\mathrm{PM}_{2.5}$, which refers to particles in the atmosphere with a diameter less than or equal to 2.5 microns, also known as lung particles $[24,25]$. The other one is a comprehensive indicator such as the air quality index
[26]. However, due to problems with the availability of data, the industrial dust, soot emissions, and other indicators in Jiangsu are not available in some years. Therefore, the air quality of 13 cities in $2000-2017$ is selected to reach the second-order (good) days to measure air pollution as the explanatory variable of this study. The higher number of days with good air quality indicates less air pollution and improvement of the air quality.

The core explanatory variable is the high-speed railway opening, as well as it is the dummy variable $(G)$. Since the time period for selecting the data is 2000-2017, this study assigns values to each city according to the situation of the opening of the high-speed rail in the 13 cities. If a city opens a high-speed railway in the same year, the value is 1 ; otherwise, the value is 0 .

In order to control the influence of other factors, this study selects a series of control variables. A large number of researchers have verified that the level of economic development is an important factor influencing atmospheric pollution [27], but scholars examining different relationships have different conclusions. Therefore, based on the practice of the previous literature, this study uses per capita GDP (PGDP) to measure the economic level and joins the square of the per capita GDP to see whether the relationship between the air pollution and economic development level is in line with the environmental Kuznets curve. Usually the industrial structure is closely related to air pollution. The tertiary industry, which is represented by the service industry, is considered to be a clean and low-pollution industry, and the high output value of the tertiary industry means less air pollution. Therefore, this study uses the third industry added value $\left(T_{3}\right)$ as a measure of the industrial structure to test the impact of the industrial structure on the air pollution. The influence of the residents on the atmospheric environment cannot be ignored, and the degree of emphasis on the atmospheric environment and the intensity of investment affect the degree of atmospheric pollution. If the residents have higher demands for good air and more investment in governance, the air pollution will be improved. The per capita disposable income of urban residents is used as a measure of the per capita income (PI). In addition, there is a body of research work that shows that urbanization $(U)$ and foreign direct investment (FDI) have an impact on air pollution [28]. Therefore, this study adopts "urban population/total population" and "actual use of foreign direct investment" to obtain two indicators of the urbanization rate and foreign direct investment level to capture the impact of the changes.

The data samples used in this study are the panel data for 13 cities in Jiangsu province from 2000 to 2017. The sample interval was determined to be 2000-2017 for two reasons. On the one hand, the decision was limited by the availability of the required data in the Jiangsu Environmental Statistics Yearbook. The air pollution indicators before 2000 were seriously lacking, so the decision was made to start in 2000. On the other hand, the development of China's high-speed rail network began in 2000, so it was decided that this was a good time to begin to study the impact of Jiangsu's highspeed rail. This allows a relatively complete high-speed rail 
development time period, and the results are more credible as a consequence of this. All the original data are from the Jiangsu Statistical Yearbook and Jiangsu Environmental Statistics Yearbook. Table 1 shows the descriptive statistics for each variable. In order to eliminate the heteroscedasticity of the data and make the data comparable, the original data are logarithmically processed, and the following variables are the logarithmic results.

\section{Empirical Analysis}

4.1. Basic Regression Results. In this study, the effects of highspeed rail opening on air pollution are investigated on the basis of the fixed time effect and urban effect. The main regression results are shown in Table 2.

As can be seen from Table 2, column (1) only examines the effect of the high-speed rail opening on good atmospheric days. The results show that the regression coefficient of the dummy variable is positive and is statistically significant at $1 \%$, which indicates that compared with the cities where the there is no high-speed rail, the cities with highspeed rail increase their air quality into the second-grade days, and the air quality is improved. Accordingly, Hypothesis 1 is preliminarily proven. Columns (2)-(6) are the results of the stepwise addition of the control variables on the basis of column (1). It can be found that the coefficient of the high-speed rail opening variable is still significantly positive, which is consistent with the previous research findings, to some extent [29]. This shows that the opening of high-speed rail will reduce air pollution. After gradually adding the regression results of the other control variables, the high-speed rail opening shows no significant change in the magnitude, symbol, and significant level of the coefficient of good weather, which indicates that the positive effect between the high-speed rail opening and air quality reaching the second-grade days is robust. Accordingly, Hypothesis 1 is verified. Jiangsu is a province with a relatively slow development of high-speed railway construction; there are high-speed railways only in the southern and some northern areas. However, the environmental benefits of the highspeed rail have already appeared. Opening high-speed railway lines and increasing the number of high-speed rail cities can alleviate the current severe air pollution in the province.

The regression results of the control variables show that there is no "inverted $U$ " relationship between Jiangsu's economic development and atmospheric pollution, so the Kuznets hypothesis is not established here. This conclusion is inconsistent with the conclusions obtained that $\mathrm{SO}_{2}$ and $\mathrm{PM}_{2.5}$ are air pollution indicators [30,31]. It can be seen that the conclusions in respect of air pollution indicators are inconsistent. Personal income is significantly positive at the $10 \%$ level. This may be due to an increase in the personal income of the residents and an improvement in their quality of life, which in turn increases their requirements for the atmospheric environment. The increase in income also results in an increase in the government tax revenues, which will satisfy the funding needs for air pollution control. The level of urbanization is also an important factor in increasing the air quality to reach the second-grade days. The possible reason is that Jiangsu has a higher level of urbanization. The data show that the urbanization rate of all cities in 2017 was above $50 \%$, and more than half of the cities reached more than $65 \%$. This shows that the development of urbanization in Jiangsu has been quite reasonable, and it has not blindly pursued population growth and urban expansion. The high demands placed on the environment in the orderly and rational urbanization process have promoted the government's emphasis on the environment and thereby improved the atmospheric environment. The effect of foreign direct investment on the atmospheric good days is negative and significant at the $5 \%$ level. This shows that foreign direct investment has a significant positive impact on air pollution, which supports the conclusions of other scholars [32, 33]. Because of the problems of environmental protection awareness, inadequate regulations, and low regulatory standards in Jiangsu's early open trade, it attracted a large number of pollution-intensive foreign direct investment. This exacerbates the degree of atmospheric pollution and reduces the number of days with good air quality.

\subsection{Robustness Test}

4.2.1. Trend Test. An important hypothesis for using the DID method to study the effects of high-speed rail opening is that if there is no high-speed rail opening event, the development trend between the treatment group and the control group is consistent, and there is no systematic difference over time. From the research object of this paper, the high-speed railway line planning is obviously affected by the conditions of various aspects of the cities. Those cities with a high economic performance level, perfect infrastructure, and a large city scale often give priority to highspeed rail. Therefore, compared with the cities without highspeed rail, the cities with high-speed railways are inconsistent. In order to solve this problem, it is necessary to test whether there are systematic differences.

This study examines the regional problems of individual provinces. From the perspective of the cities in this study, the provincial and nonprovincial cities can be divided into cities within the radiation range of Nanjing, and we examine their economic, cultural, and transportation development. Their development levels are all fast, so when the high-speed rail planning is carried out, the relevant departments will give priority to these cities. Their environmental attention and the ability to control pollution will have an impact on the air pollution and improve the pollution levels. Therefore, in this hypothesis, this type of city is most likely to violate the common trend assumption. If the city itself significantly affects the explanatory variables, this indicates that there are systematic differences in different regions. If the effect is not significant, this indicates that the degree of air pollution is not affected by the city level [34]. The results for this type of city are shown in Table 3. The observations show that the impact of the surrounding cities on the good weather is not significant. This indicates that if the effect of high-speed rail opening is not considered, there is no systematic difference 
TABle 1: Statistical description of major variables.

\begin{tabular}{|c|c|c|c|c|c|c|c|}
\hline Variables & Economic meaning & Unit & Sample & Mean & $\begin{array}{l}\text { Standard } \\
\text { deviation }\end{array}$ & Minimum & Maximum \\
\hline Goodday & $\begin{array}{l}\text { Days of air quality reaching the second order } \\
\text { (good) }\end{array}$ & Day & 234 & 287.269 & 61.647 & 145 & 362 \\
\hline G & High-speed railway opening virtual variable & - & 234 & 0.163 & 0.370 & 0 & 1 \\
\hline PGDP & GDP/total population & Yuan & 234 & 45201.160 & 34380 & 3993 & 145556 \\
\hline$T_{3}$ & Third industry added value & $\begin{array}{l}\text { Billion } \\
\text { Yuan }\end{array}$ & 234 & 39.150 & 5.962 & 26.8 & 58.390 \\
\hline PI & Per capita disposable income of urban residents & Yuan & 234 & 19403.620 & 11226.790 & 4617 & 54341 \\
\hline FDI & Actual use of foreign direct investment & $\begin{array}{l}\text { Billion } \\
\text { Yuan }\end{array}$ & 234 & 0.044 & 0.030 & 0.004 & 0.201 \\
\hline$U$ & Urban population/total population & $\%$ & 234 & 0.532 & 0.164 & 0.137 & 0.980 \\
\hline
\end{tabular}

TABLE 2: Basic regression results.

\begin{tabular}{|c|c|c|c|c|c|c|}
\hline & $\begin{array}{c}(1) \\
\text { Goodday }\end{array}$ & $\begin{array}{c}(2) \\
\text { Goodday }\end{array}$ & $\begin{array}{c}(3) \\
\text { Goodday }\end{array}$ & $\begin{array}{c}(4) \\
\text { Goodday }\end{array}$ & $\begin{array}{c}(5) \\
\text { Goodday }\end{array}$ & $\begin{array}{c}(6) \\
\text { Goodday }\end{array}$ \\
\hline$G$ & $\begin{array}{c}0.354^{* * *} \\
(0.032)\end{array}$ & $\begin{array}{c}0.184^{* * *} \\
(0.047)\end{array}$ & $\begin{array}{c}0.184^{* * *} \\
(0.047)\end{array}$ & $\begin{array}{c}0.189^{* * *} \\
(0.047)\end{array}$ & $\begin{array}{c}0.202^{* * *} \\
(0.046)\end{array}$ & $\begin{array}{c}0.215^{* * *} \\
(0.045)\end{array}$ \\
\hline PGDP & - & $\begin{array}{l}-0.025 \\
(0.018)\end{array}$ & $\begin{array}{l}-0.029 \\
(0.057)\end{array}$ & $\begin{array}{r}-0.152^{*} \\
(0.087)\end{array}$ & $\begin{array}{l}-0.136 \\
(0.086)\end{array}$ & $\begin{array}{l}-0.082 \\
(0.086)\end{array}$ \\
\hline $\mathrm{PGDP}^{2}$ & - & $\begin{array}{c}-2.47 \times 10^{-11 * * *} \\
\left(5.01 \times 10^{-12}\right)\end{array}$ & $\begin{array}{c}-2.49 \times 10^{-11 * * *} \\
\left(5.36 \times 10^{-12}\right)\end{array}$ & $\begin{array}{c}-3.2 \times 10^{-11 * * *} \\
\left(6.87 \times 10^{-12}\right)\end{array}$ & $\begin{array}{c}-3.12 \times 10^{-11 * * *} \\
\left(6.79 \times 10^{-12}\right)\end{array}$ & $\begin{array}{c}-3.88 \times 10^{-11 * * *} \\
\left(7.14 \times 10^{-12}\right)\end{array}$ \\
\hline$T_{3}$ & - & - & $\begin{array}{c}0.004 \\
(0.053)\end{array}$ & $\begin{array}{l}-0.018 \\
(0.054)\end{array}$ & $\begin{array}{l}-0.025 \\
(0.053)\end{array}$ & $\begin{array}{l}-0.009 \\
(0.052)\end{array}$ \\
\hline PI & - & - & - & $\begin{array}{l}0.235^{*} \\
(0.127)\end{array}$ & $\begin{array}{l}0.129^{*} \\
(0.131)\end{array}$ & $\begin{array}{l}0.059^{*} \\
(0.130)\end{array}$ \\
\hline$U$ & - & - & - & - & $\begin{array}{c}0.552^{* * *} \\
(0.196)\end{array}$ & $\begin{array}{c}0.598^{* * *} \\
(0.193)\end{array}$ \\
\hline FDI & - & - & - & - & - & $\begin{array}{c}-0.066^{* * *} \\
(0.022)\end{array}$ \\
\hline Constant & $\begin{array}{c}5.645^{* * *} \\
(0.012)\end{array}$ & $\begin{array}{c}5.946^{* * *} \\
(0.184)\end{array}$ & $\begin{array}{c}5.887^{* * *} \\
(0.771)\end{array}$ & $\begin{array}{c}5.442^{* * *} \\
(0.803)\end{array}$ & $\begin{array}{c}6.188^{* * *} \\
(0.833)\end{array}$ & $\begin{array}{c}5.700^{* * * *} \\
(0.834)\end{array}$ \\
\hline Time effect & Control & Control & Control & Control & Control & Control \\
\hline Urban effect & Control & Control & Control & Control & Control & Control \\
\hline Within $R^{2}$ & 0.023 & 0.210 & 0.214 & 0.223 & 0.253 & 0.284 \\
\hline Samples & 234 & 234 & 234 & 234 & 234 & 234 \\
\hline
\end{tabular}

${ }^{* * *},{ }^{* *}$, and ${ }^{*}$ indicate the level of significance through $1 \%, 5 \%$, and $10 \%$, respectively.

in the trend of air pollution between the treatment group and the control group, which indicates that the regression results in Table 2 are credible.

4.2.2. Counterfactual Test. In order to further test the robustness of the results, this study draws on the existing research and conducts counterfactual testing by changing the time of the occurrence of events [35]. This approach is taken because, in addition to the impact of high-speed rail opening on air pollution, other external or random factors will also affect the air pollution situation in Jiangsu, which will lead to the failure of the previous hypothesis test results. In order to eliminate the influence of such factors, this study will extend the high-speed rail opening time of each city to two or three years in advance in order to examine its impact on the air pollution in cities along the route. If the result shows that the coefficient of the high-speed rail dummy variable is significantly positive, this would indicate that the improvement in the air pollution may be caused by other factors rather than the opening of the high-speed rail. Conversely, if the coefficient of the dummy variable is not significant, this would indicate that the improvement in the air pollution is the result of the opening of the high-speed rail. The results of the counterfactual test are shown in Table 4.

Columns (1) and (2) of Table 4 show the results of the counterfactual experiments in which the high-speed rail is opened two years or three years in advance, respectively. The results show that the regression coefficient of high-speed rail is not significant, which indicates that the improvement in the air pollution in Jiangsu province is not caused by other factors; it is caused by the opening of the high-speed rail.

\subsection{Further Inspection: Inspection of the Urban Air Pollution} Improvement in the Central City Circle. According to Hypothesis 2, the opening of the high-speed railway improves the urban pollution control capacity within the circle through the experience of the central city, and it also 
TABLE 3: Common trend test.

\begin{tabular}{|c|c|}
\hline & $\begin{array}{c}(1) \\
\text { Goodday }\end{array}$ \\
\hline Central & $\begin{array}{l}-2.146 \\
(0.495)\end{array}$ \\
\hline PGDP & $\begin{array}{l}0.001^{*} \\
(0.001)\end{array}$ \\
\hline $\mathrm{PGDP}^{2}$ & $\begin{array}{c}-7.90 \times 10^{-9 * *} \\
\left(3.35 \times 10^{-9}\right)\end{array}$ \\
\hline$T_{3}$ & $\begin{array}{l}0.678^{* *} \\
(0.394)\end{array}$ \\
\hline PI & $\begin{array}{l}-0.003 \\
(0.002)\end{array}$ \\
\hline$U$ & $\begin{array}{c}1.107^{* * *} \\
(0.300)\end{array}$ \\
\hline FDI & $\begin{array}{c}-1.574^{*} \\
(0.469)\end{array}$ \\
\hline Constant & $\begin{array}{c}6.514^{* * * *} \\
(0.706)\end{array}$ \\
\hline Time effect & Control \\
\hline Urban effect & Control \\
\hline Within $R^{2}$ & 0.282 \\
\hline Samples & 234 \\
\hline
\end{tabular}

${ }^{* * *},{ }^{* *}$, and ${ }^{*}$ indicate the level of significance through $1 \%, 5 \%$, and $10 \%$, respectively.

TABLE 4: Counterfactual experiment results.

\begin{tabular}{|c|c|c|}
\hline & $\begin{array}{c}(1) \\
\text { Goodday }\end{array}$ & $\begin{array}{c}(2) \\
\text { Goodday }\end{array}$ \\
\hline L2_G & $\begin{array}{c}0.216 \\
(0.038)\end{array}$ & - \\
\hline L3_G & - & $\begin{array}{c}0.215 \\
(0.038)\end{array}$ \\
\hline PGDP & $\begin{array}{l}-0.003 \\
(0.085)\end{array}$ & $\begin{array}{c}0.049 \\
(0.087)\end{array}$ \\
\hline $\mathrm{PGDP}^{2}$ & $\begin{array}{c}-3.00 \times 10^{-11 * * *} \\
\left(6.12 \times 10^{-12}\right)\end{array}$ & $\begin{array}{c}-2.40 \times 10^{-11 * * *} \\
\left(5.91 \times 10^{-12}\right)\end{array}$ \\
\hline$T_{3}$ & $\begin{array}{l}-0.028 \\
(0.051)\end{array}$ & $\begin{array}{l}-0.030 \\
(0.051)\end{array}$ \\
\hline PI & $\begin{array}{l}-0.055 \\
(0.129)\end{array}$ & $\begin{array}{l}-0.240 \\
(0.132)\end{array}$ \\
\hline$U$ & $\begin{array}{c}0.509^{* * * *} \\
(0.188)\end{array}$ & $\begin{array}{l}0.443^{* *} \\
(0.188)\end{array}$ \\
\hline FDI & $\begin{array}{c}-0.053^{* *} \\
(0.022)\end{array}$ & $\begin{array}{c}-0.046^{*} \\
(0.022)\end{array}$ \\
\hline Constant & $\begin{array}{c}6.500^{* * *} \\
(0.824)\end{array}$ & $\begin{array}{c}6.872^{* * * *} \\
(0.834)\end{array}$ \\
\hline Time effect & Control & Control \\
\hline Urban effect & Control & Control \\
\hline Within $R^{2}$ & 0.313 & 0.315 \\
\hline Samples & 234 & 234 \\
\hline
\end{tabular}

***, ${ }^{* *}$, and ${ }^{*}$ indicate the level of significance through $1 \%, 5 \%$, and $10 \%$, respectively.

accelerates the diffusion effect of the green economy effect of the central city, which strengthens the green spillover effect of the central city and achieves the effect of improving the air quality. Therefore, the quality of the city's atmosphere in the central city circle has been greatly improved. To verify this hypothesis, the following regression equation was constructed for testing:

$$
\text { Goodday }_{i, t}=\alpha_{i, t}+\beta G_{i, t}+\lambda X_{i, t}+\gamma_{t}+\mu_{i}+\varepsilon_{i, t} .
$$

The distance from Shanghai to less than 300 kilometers away is defined as 1 , and the distance from Shanghai to more than 300 kilometers away is defined as 0 . Take the variable $S$ and then multiply $S$ by $G$ to get the interaction term $G \_S$. If it is significant, it shows that compared with the high-speed 
TABle 5: Test of spillover effects in the central city circle.

\begin{tabular}{|c|c|c|c|c|c|c|}
\hline & $\begin{array}{c}(1) \\
\text { Goodday }\end{array}$ & $\begin{array}{c}(2) \\
\text { Goodday }\end{array}$ & $\begin{array}{c}(3) \\
\text { Goodday }\end{array}$ & $\begin{array}{c}(4) \\
\text { Goodday }\end{array}$ & $\begin{array}{c}(5) \\
\text { Goodday }\end{array}$ & $\begin{array}{c}(6) \\
\text { Goodday }\end{array}$ \\
\hline$G \_S$ & $\begin{array}{l}0.121^{* *} \\
(0.035)\end{array}$ & $\begin{array}{l}0.066^{* *} \\
(0.060)\end{array}$ & $\begin{array}{l}0.066^{* *} \\
(0.060)\end{array}$ & $\begin{array}{l}0.057^{*} \\
(0.060)\end{array}$ & $\begin{array}{l}0.063^{*} \\
(0.059)\end{array}$ & $\begin{array}{l}0.090^{*} \\
(0.059)\end{array}$ \\
\hline PGDP & - & $\begin{array}{l}-0.027 \\
(0.020)\end{array}$ & $\begin{array}{l}-0.028 \\
(0.060)\end{array}$ & $\begin{array}{l}-0.127 \\
(0.091)\end{array}$ & $\begin{array}{l}-0.112 \\
(0.091)\end{array}$ & $\begin{array}{l}-0.054 \\
(0.092)\end{array}$ \\
\hline $\mathrm{PGDP}^{2}$ & - & $\begin{array}{c}-1.61 \times 10^{-11 * * *} \\
\left(6.05 \times 10^{-12}\right)\end{array}$ & $\begin{array}{c}-1.62 \times 10^{-11 * *} \\
\left(6.35 \times 10^{-12}\right)\end{array}$ & $\begin{array}{c}-2.15 \times 10^{-11 * * *} \\
\left(7.36 \times 10^{-12}\right)\end{array}$ & $\begin{array}{c}-1.96 \times 10^{-11 * * *} \\
\left(7.33 \times 10^{-12}\right)\end{array}$ & $\begin{array}{c}-2.78 \times 10^{-11 * * *} \\
\left(7.86 \times 10^{-12}\right)\end{array}$ \\
\hline$T_{3}$ & - & ( & $\begin{array}{c}0.001 \\
(0.055)\end{array}$ & $\begin{array}{l}-0.016 \\
(0.056)\end{array}$ & $\begin{array}{l}-0.022 \\
(0.055)\end{array}$ & $\begin{array}{l}-0.007 \\
(0.055)\end{array}$ \\
\hline PI & - & - & - & $\begin{array}{c}0.189 \\
(0.132)\end{array}$ & $\begin{array}{c}0.093 \\
(0.137)\end{array}$ & $\begin{array}{c}0.018 \\
(0.138)\end{array}$ \\
\hline$U$ & - & - & - & - & $\begin{array}{l}0.477^{* *} \\
(0.203)\end{array}$ & $\begin{array}{l}0.520^{* *} \\
(0.201)\end{array}$ \\
\hline FDI & - & - & - & - & - & $\begin{array}{c}-0.062^{* * *} \\
(0.024)\end{array}$ \\
\hline Constant & $\begin{array}{c}5.652^{* * *} \\
(0.011)\end{array}$ & $\begin{array}{c}5.957^{* * *} \\
(0.199)\end{array}$ & $\begin{array}{c}5.940^{* * * *} \\
(0.799)\end{array}$ & $\begin{array}{c}5.596^{* * * *} \\
(0.832)\end{array}$ & $\begin{array}{c}6.249^{* * *} \\
(0.869)\end{array}$ & $\begin{array}{c}5.783^{* * * *} \\
(0.875)\end{array}$ \\
\hline Time effect & Control & Control & Control & Control & Control & Control \\
\hline Urban effect & Control & Control & Control & Control & Control & Control \\
\hline Within $R^{2}$ & 0.056 & 0.155 & 0.155 & 0.164 & 0.186 & 0.213 \\
\hline Samples & 234 & 234 & 234 & 234 & 234 & 234 \\
\hline
\end{tabular}

${ }^{* * *},{ }^{* *}$, and ${ }^{*}$ indicate the level of significance through $1 \%, 5 \%$, and $10 \%$, respectively.

TABLE 6: Inspection of impact mechanism using rural electricity consumption data.

\begin{tabular}{|c|c|c|c|c|c|c|}
\hline & $\begin{array}{c}(1) \\
\text { Goodday }\end{array}$ & $\begin{array}{c}(2) \\
\text { Goodday }\end{array}$ & $\begin{array}{c}(3) \\
\text { Goodday }\end{array}$ & $\begin{array}{c}(4) \\
\text { Goodday }\end{array}$ & $\begin{array}{c}(5) \\
\text { Goodday }\end{array}$ & $\begin{array}{c}(6) \\
\text { Goodday }\end{array}$ \\
\hline$G \_E$ & $\begin{array}{c}0.043^{* *} \\
(0.030)\end{array}$ & $\begin{array}{c}0.008^{* * *} \\
(0.002)\end{array}$ & $\begin{array}{c}0.008^{* * *} \\
(0.002)\end{array}$ & $\begin{array}{c}0.008^{* * *} \\
(0.002)\end{array}$ & $\begin{array}{c}0.009^{* * *} \\
(0.002)\end{array}$ & $\begin{array}{c}0.009^{* * *} \\
(0.002)\end{array}$ \\
\hline PGDP & - & $\begin{array}{r}-0.024 \\
(0.019)\end{array}$ & $\begin{array}{l}-0.026 \\
(0.057)\end{array}$ & $\begin{array}{c}-0.147^{*} \\
(0.087)\end{array}$ & $\begin{array}{l}-0.131 \\
(0.086)\end{array}$ & $\begin{array}{l}-0.077 \\
(0.086)\end{array}$ \\
\hline $\mathrm{PGDP}^{2}$ & - & $\begin{array}{c}-2.51 \times 10^{-11 * * *} \\
\left(5.12 \times 10^{-12}\right)\end{array}$ & $\begin{array}{c}-2.52 \times 10^{-11 * * *} \\
\left(5.46 \times 10^{-12}\right)\end{array}$ & $\begin{array}{c}-3.32 \times 10^{-11 * * *} \\
\left(6.95 \times 10^{-12}\right)\end{array}$ & $\begin{array}{c}-3.15 \times 10^{-11 * * *} \\
\left(6.86 \times 10^{-12}\right)\end{array}$ & $\begin{array}{c}-3.94 \times 10^{-11 * * *} \\
\left(7.22 \times 10^{-12}\right)\end{array}$ \\
\hline$T_{3}$ & - & - & $\begin{array}{c}0.002 \\
(0.053)\end{array}$ & $\begin{array}{l}-0.020 \\
(0.054)\end{array}$ & $\begin{array}{l}-0.027 \\
(0.053)\end{array}$ & $\begin{array}{l}-0.011 \\
(0.052)\end{array}$ \\
\hline PI & - & - & - & $\begin{array}{l}0.234^{*} \\
(0.127)\end{array}$ & $\begin{array}{c}0.127 \\
(0.131)\end{array}$ & $\begin{array}{c}0.056 \\
(0.130)\end{array}$ \\
\hline$U$ & - & - & - & - & $\begin{array}{c}0.552^{* * *} \\
(0.196)\end{array}$ & $\begin{array}{c}0.599^{* * *} \\
(0.193)\end{array}$ \\
\hline FDI & - & - & - & - & - & $\begin{array}{c}-0.067^{* * *} \\
(0.022)\end{array}$ \\
\hline Constant & $\begin{array}{c}5.645^{* * *} \\
(0.012)\end{array}$ & $\begin{array}{c}5.932^{* * *} \\
(0.185)\end{array}$ & $\begin{array}{c}5.901^{* * * *} \\
(0.771)\end{array}$ & $\begin{array}{c}5.459^{* * * *} \\
(0.804)\end{array}$ & $\begin{array}{c}6.206^{* * *} \\
(0.834)\end{array}$ & $\begin{array}{c}5.711^{* * *} \\
(0.834)\end{array}$ \\
\hline Time effect & Control & Control & Control & Control & Control & Control \\
\hline Urban effect & Control & Control & Control & Control & Control & Control \\
\hline Within $R^{2}$ & 0.039 & 0.208 & 0.208 & 0.221 & 0.251 & 0.283 \\
\hline Samples & 234 & 234 & 234 & 234 & 234 & 234 \\
\hline
\end{tabular}

***, ${ }^{* *}$, and ${ }^{*}$ indicate the level of significance through $1 \%, 5 \%$, and $10 \%$, respectively.

rail cities that are not in the central economic circle of Shanghai, the cities in the Shanghai central economic circle have less pollution after the opening of the high-speed rail. The regression results are shown in Table 5 .

It can be seen in Table 5 that the coefficient of the interaction term $G \_S$ has passed the 5\% significance level, and Hypothesis 2 is verified, which indicates that the cities in the Shanghai central economic circle have increased the number of days of good weather and improved the air pollution after the opening of the high-speed railway. The results of adding the control variables at the same time are still significant, which indicates that the central city circle has significant pollution improvement capabilities. Jiangsu province is located in the economic belt of the Yangtze River Delta. Most of the cities are close to Shanghai, so they need to exploit their geographical advantages and actively open 
TABLE 7: Comparisons of high-speed rail opening impact.

\begin{tabular}{|c|c|c|c|c|c|}
\hline Study & Research area & $\begin{array}{l}\text { Research } \\
\text { period }\end{array}$ & Pollutants & Methodology & Results \\
\hline \multirow{5}{*}{$\begin{array}{l}\text { Previous } \\
\text { study }\end{array}$} & China & $2008-2015$ & Carbon dioxide & LCA & $\begin{array}{c}\text { Reduce carbon emissions by } \\
26.1 \text { million tons } \\
\text { (Wang et al. [36]) }\end{array}$ \\
\hline & 270 cities, China & $2003-2016$ & Industrial emissions per capita & DID & $\begin{array}{c}\text { Decrease by } 23.35 \% \\
\text { (Zhu et al. [29]) }\end{array}$ \\
\hline & 285 cities, China & $2003-2016$ & $\mathrm{PM}_{2.5}$ & DID & $\begin{array}{c}\text { Decrease by } 1.81 \% \\
\text { (Zhang and Feng [37]) }\end{array}$ \\
\hline & 271 cities, China & $2007-2015$ & $\begin{array}{l}\text { Sulfur dioxide, industrial waste } \\
\text { water, and industrial smoke }\end{array}$ & $\begin{array}{l}\text { Bidirectional fixed } \\
\text { effects model }\end{array}$ & $\begin{array}{l}\text { Decrease by } 2.505,1.215 \text {, } \\
\text { and } 2.505 \text { (Zhang et al. [38]) }\end{array}$ \\
\hline & $\begin{array}{l}\text { Yangtze River } \\
\text { Economic Belt, } \\
\text { China }\end{array}$ & $2007-2017$ & $\begin{array}{l}\text { Comprehensive index of } \\
\text { environmental pollution }\end{array}$ & PSM-DID & $\begin{array}{c}\text { Decrease by } 8.6 \% \\
\text { (Zhang and Zhang [16]) }\end{array}$ \\
\hline This study & $\begin{array}{l}\text { Jiangsu province, } \\
\text { China }\end{array}$ & $2000-2017$ & $\begin{array}{c}\text { Reach the second-order (good) } \\
\text { days }\end{array}$ & DID & Increase by $21.5 \%$ \\
\hline
\end{tabular}

high-speed rail lines in the central city circle to better improve the traffic and environmental problems in the central and northern parts of Jiangsu.

After the above analysis, the study concludes that the opening of high-speed rail can reduce air pollution and improve the air quality. However, the mechanism of the impact of high-speed rail pollution remains to be tested. Therefore, this study chooses to multiply the high-speed rail with other pollution items that may be affected and observe whether the influence coefficient of the interaction term is significant. If it is significant, it proves that the high-speed rail improvement effect is significant. Here, the rural electricity consumption index is used to indicate the level of rural modernization $(E)$. Because most of the high-speed rail infrastructure is built in rural areas around the city, its construction and operation may bring pollution to the surrounding rural areas. The results are shown in Table 6. The regression results show that the coefficient of the interaction term is significantly positive whether or not the control variable is added, which indicates that the opening of the high-speed rail does not exacerbate the air pollution in rural areas. On the contrary, it increases the number of good weather days and improves the air pollution. The opening of the high-speed railway brings about the transfer and rational distribution of the industry. The rural areas receive financial and technical support through the intermediary role of the high-speed rail, it helps to eliminate backward technologies, new industrial chains are upgraded, and the service industries are developed, all of which improve the air quality.

In order to better interpret the above results, these results are compared with those of previous studies, as shown in Table 7. Results in this study indicate that the opening of high-speed railway has caused the corresponding city's good day to increase significantly by $21.5 \%$, that is, the air pollution level is reduced by $21.5 \%$, which are consistent with previous research results that the opening of high-speed railway can mitigate air pollution to a greater extent. This shows that the obtained results have certain reference value.

\section{Conclusions}

The development of high-speed railways is an important way for the country to improve transportation and promote the economy. The opening of high-speed railways has facilitated people's travel by greatly shortening the spatial distance between cities and promoting exchanges between cities, but air pollution has increased significantly since the start of the 21st century, and the problem is getting worse. A key issue today is determining how to accurately grasp the relationship between the opening of high-speed rail and air pollution. In this study, the DID method is used to select the panel data of Jiangsu province in 2000-2017 to examine whether the opening of high-speed rail reduces air pollution. The results show that (1) the opening of high-speed rail significantly increases cities' good day by $21.5 \%$ and improves the air quality, which is still valid after a number of robustness tests. As for control variables, there is no inverted " $U$ " relationship between the level of economic development and air pollution, which shows that the Kuznets hypothesis is not established in Jiangsu province. In addition, the increased personal income and urbanization significantly improve air quality, whereas the increase in FDI worsens air pollution. (2) The reduction of pollution caused by the opening of the high-speed rail is also related to the regional location of the city. Compared with other cities with highspeed rail, the cities near to Shanghai in the central city circle bring greater improvements to air pollution. (3) When the high-speed rail coexists with other possible pollutants, the opening of high-speed rail increases the number of good weather, thereby mitigating atmospheric pollution. From the above research, the following countermeasures are proposed.

Firstly, the opening of the high-speed rail can not only promote the rapid growth of the regional economy but also improve the city's air pollution. Therefore, it is necessary to rationally plan the construction of high-speed rail, which ensures the stability of the atmospheric environment and achieves a win-win situation for the economy and the environment in the context of steady economic growth. 
Secondly, the central city circle has a more significant role in mitigating air pollution, which implies construction of highspeed rail should be carried out from the cities in the central circle. Specifically, the traffic barrier between the cities in the provinces near Shanghai might be broken to make better use of the green effect of high-speed rail and narrow the economic and environmental quality differences between cities. Thirdly, it is essential to rationally upgrade industrial structure, vigorously develop modern service industries, and promote the integration of the manufacturing and service industries. At the same time, it is important to improve the infrastructure construction, improve the efficiency of FDI, and improve the laws and regulations related to attracting investment, thereby increasing the green characteristics of FDI.

\section{Data Availability}

The data used to support the findings of this study are available from the corresponding author upon request.

\section{Conflicts of Interest}

The authors declare that there are no conflicts of interest regarding the publication of this paper.

\section{Acknowledgments}

This study was supported by a project of the National Social Science Foundation of China (19BGL196 and 19BJL033), "Qing Lan Project" of Jiangsu Province, Social Science Excellent Young Scholars of Jiangsu Province, a Key Project of Philosophy and Social Science of Jiangsu, China (2018SJZDI054), and a project funded by the Priority Academic Program Development of Jiangsu Higher Education Institutions (PAPD).

\section{References}

[1] J. F. Su, Y. M. Sun, and Y. Y. Liu, "Complexity study on the unsteady flow field and aerodynamic noise of high-speed railways on bridges," Complexity, vol. 2018, Article ID 7162731, 16 pages, 2018.

[2] A. Hoekstra, M. Steinbuch, and G. Verbong, "Creating agentbased energy transition management models that can uncover profitable pathways to climate change mitigation," Complexity, vol. 2017, Article ID 1967645, 23 pages, 2017.

[3] Y. Zhao, Y. Li, and Q. Chen, "Analysis of a stochastic susceptible-infective epidemic model in a polluted atmospheric environment," Complexity, vol. 2019, Article ID 3184903, 14 pages, 2019.

[4] Y. F. Wang and P. F. Ni, "Economic growth spillover and regional space optimization under the influence of high speed railway," China Industrial Economics, vol. 2, pp. 21-36, 2016.

[5] Y. Y. Wang and X. Chen, "Research on the impact of highspeed rail commuting cost on regional income gap-based on the analysis of urban clustering effect," Price: Theory \&Practice, vol. 38, no. 9, pp. 95-98, 2018.

[6] H. C. Li, T. Linda, and S. X. Hu, "The impact of China's highspeed railway on economic agglomeration and equalization of cities along the line," The Journal of Quantitative \& Technical Economics, vol. 33, no. 11, pp. 127-143, 2016.
[7] J. F. Wang and S. Zhai, "Research on the influence of highspeed rail economic effect on the transformation of regional development mechanism," East China Economic Management, vol. 29, no. 11, pp. 76-80, 2015.

[8] M. Z. Zhang, D. H. Yu, and Y. Y. Sun, "Study on the remolding effect of high-speed railway opening on urban population distribution pattern," Chinese Journal of Population Science, vol. 32, no. 5, pp. 94-128, 2018.

[9] J. F. Liu and Y. Zhao, "The impact of high-speed rail on the balanced development of China's urbanization-based on the analysis of panel data of 163 prefecture-level cities in the central and western regions," Urban Problem, vol. 37, no. 5, pp. 15-25, 2018.

[10] Z. K. Huang, J. Y. Liu, and G. R. Ma, "Geographic location, high-speed rail and information: evidence from the Chinese IPO market," The Journal of World Economy, vol. 39, no. 10, pp. 127-149, 2016.

[11] Y. Long, H. L. Zhao, X. D. Zhang et al., "Venture capital under the spatiotemporal compression-high-speed rail opening and regional changes of venture capital," Economic Research Journal, vol. 52, no. 4, pp. 195-208, 2017.

[12] L. W. Zhao and C. O. A. Otoo, "Stability and complexity of a novel three-dimensional environmental quality dynamic evolution system," Complexity, vol. 2019, Article ID 3941920, 11 pages, 2019.

[13] H. B. Zhang, "Research on low carbon comparative advantage of high speed railway in China," Macroeconomics, vol. 33, no. 7, pp. 17-49, 2011.

[14] R. B. Liang and P. H. Xi, "Heterogeneity of rail transit to air pollution: an empirical study based on RDID method," China Industrial Economics, vol. 34, no. 3, pp. 83-98, 2016.

[15] L. H. Liu and H. C. Li, "Study on the impact of high speed rail and urban traffic on urban carbon footprint," Journal of Beijing Jiaotong University (Social Science Edition), vol. 16, no. 4, pp. 17-29, 2017.

[16] Y. Q. Zhang and J. Y. Zhang, "Study on the impact of highspeed railway opening in the Yangtze river economic belt on environmental pollution," Contemporary Economic Management, vol. 41, no. 41, pp. 35-42, 2019.

[17] M. R. Jiang, Y. Fan, Y. Xia et al., "Comprehensive assessment of short-term effects of national high-speed rail construction investment on national economy and environment," China Population Resources and Environment, vol. 27, no. 2, pp. 75-83, 2017.

[18] Y. Yue, T. Wang, S. Liang et al., "Life cycle assessment of high speed rail in China," Transportation Research Part D: Transport and Environment, vol. 41, no. 12, pp. 367-376, 2015.

[19] X. J. Zhou, "High-speed railway boosts China's low-carbon economy," Bulletin of Chinese Academy of Sciences, vol. 21, no. 4, pp. 452-461, 2011.

[20] H. Mohring, J. Schroeter, and P. Wiboonchutikula, "The values of waiting time, travel time, and a seat on a bus," The RAND Journal of Economics, vol. 18, no. 1, pp. 40-56, 1987.

[21] K. Z. Zhang and D. J. Tao, "Economic distribution effect of transportation infrastructure: evidence from the opening of high speed rail," Economics Dynamics, vol. 57, no. 6, pp. $62-73,2016$.

[22] O. Ashenfelter and D. Card, "Using the longitudinal structure of earnings to estimate the effect of training programs," The Review of Economics and Statistics, vol. 67, no. 4, pp. 648-660, 1985.

[23] W. G. Tang and S. H. Zhang, "Modeling and computation of transboundary pollution game based on joint implementation mechanism," Complexity, vol. 2019, Article ID 1081972, 18 pages, 2019. 
[24] H. J. Li, D. Q. Zhou, and Y. J. Wei, "Factors affecting air pollution in major cities in China-a study based on analysis of pollution sources," Ecological Economy, vol. 34, no. 4, pp. 197-203, 2018.

[25] M. Wang and Y. Huang, "China's environmental pollution and economic growth," China Economic Quarterly, vol. 14, no. 2, pp. 557-578, 2015.

[26] H. J. Liu and G. J. Du, "Spatial pattern and distribution dynamic evolution of air pollution in China's cities-based on the empirical analysis of AQI and six sub-item contaminants in 161 cities," Economic Geography, vol. 36, no. 10, pp. 33-38, 2016.

[27] Q. Li and H. Q. Yao, "Study on efficiency and influencing factors of air pollution control in Beijing-Tianjin-Hebei urban agglomeration,” Ecological Economy, vol. 8, pp. 188-192, 2018.

[28] Q. Fu, X. M. Zhang, and Y. J. Zhang, "Bidirectional coupling between environmental pollution and economic growth, energy consumption, FDI and urbanization," East China Economic Management, no. 1, pp. 83-91, 2017.

[29] S. J. Zhu, S. S. Yin, and T. L. Zhong, "Does the high-speed rail opening inhibit urban environmental pollution?" East China Economic Management, vol. 33, no. 3, pp. 52-57, 2019.

[30] Y. Wang, C. C. Wang, J. Zhao et al., "Research on the Kuznets relationship of $\mathrm{SO}_{2}$ emission environment in Jiangsu province-based on the analysis of semi-parametric panel data model," China Environmental Science, vol. 36, no. 10, pp. 3143-3149, 2016.

[31] X. Li, J. H. Cao, and X. Sun, "Analysis of the influence of urbanization on haze pollution from the perspective of space-taking the Yangtze River Delta region as an example," Journal of Environmental Economic, vol. 2, no. 2, pp. 81-92, 2017.

[32] B. Copeland and S. Taylor, "Trade, growth and the environment," Journal of Economic Literature, vol. 42, no. 1, pp. 7-71, 2014.

[33] Y. L. Leng, G. M. Xian, and S. Z. Du, "Foreign direct investment and smog pollution-an empirical analysis based on Chinese provincial panel data," Journal of International Trade, vol. 41, no. 12, pp. 74-84, 2015.

[34] R. M. Liu and R. J. Zhao, "Does the National High-tech Zone promote regional economic development? - strategy based on the difference-in-differences method," Management World, vol. 31, no. 8, pp. 30-38, 2015.

[35] X. X. Liu, H. Zhang, and X. Cheng, "The impact of high-speed rail opening on urban real estate price-based on the study of the difference-in-differences model," Inquiry Into Economic Issues, vol. 39, no. 8, pp. 28-38, 2018.

[36] C. X. Wang, Y. Miao, Y. Wu et al., "Carbon reduction effects and interaction of economy and environment of high-speed railway transportation in China," China Population, Resources and Environment, vol. 27, no. 9, pp. 171-177, 2017.

[37] H. Zhang and F. Feng, "Green high-speed railway: does highspeed railway reduce haze pollution?" China Journal of Economics, vol. 6, no. 3, pp. 114-147, 2019.

[38] M. Z. Zhang, D. H. Yu, and T. Sun, "The impact of high-speed railway's opening on the green reconstruction of urban production system," China Population, Resources and Environment, vol. 29, no. 7, pp. 41-49, 2019. 